\title{
VIVER E MORRER DE ACORDO COM A NATUREZA
}

\author{
VIVIR Y MURIR SEGÚN LA NATURALEZA
}

LIVE AND DIE ACCORDING TO NATURE

\section{VIVRE ET MOURIR SELON LA NATURE}

DOI: $10.22481 /$ rbba.v10i01.8764

Jasson da Silva Martins Universidade Estadual do Sudoeste da Bahia, Bahia, Brasil ORCID: https://orcid.org?0000-0003-4851-5225

ID Lattes: http://lattes.cnpq.br/4462018626227385 Endereço eletrônico: jassonfilos@ gmail.com

\section{RESUMO}

O momento atual é oportuno para uma reflexão sobre o valor da vida através do viver e das escolhas. Viver e morrer de acordo com a natureza exige que pensemos nos limites não apenas da vida, mas também da própria razão que a justifica. A forma escolhida para fazer essa abordagem é a filosofia Estoica, através da reflexão sobre a providência, o destino e nossas escolhas.

Palavras-chave: Providência; Destino; Liberdade; Escolha.

\section{RESUMEN}

El momento actual es oportuno para una reflexión sobre el valor de la vida, a través del vivir y la elección. Vivir y morir según la naturaleza nos obliga a pensar en los límites no solo de la vida, sino también en la razón misma que la justifica. El camino elegido para tomar este enfoque es la filosofía estoica, a través de la reflexión sobre la providencia, el destino y nuestras elecciones.

Palabras clave: Providencia; Destino; Libertad; Elección. 


\begin{abstract}
The present moment is opportune for a reflection on the value of life through living and choices. Living and dying according to nature requires us to think about the limits not only of life, but also of the very reason that justifies it. The way chosen to take this approach is Stoic philosophy, through reflection on providence, fate, and our choices.
\end{abstract}

Keywords: Providence. Destiny; Freedom; Choice.

\title{
RÉSUMÉ
}

Le moment présent est propice à une réflexion sur la valeur de la vie, en vivant et en faisant des choix. Vivre et mourir selon la nature nous oblige à penser non seulement aux limites de la vie, mais aussi à la raison même qui la justifie. La voie choisie pour faire cette démarche est la philosophie stoïque, à travers une réflexion sur la providence, le destin et nos choix.

Mots-clés: Providence; Destin; Liberté; Choix.

\section{INTRODUÇÃO}

O atual momento de nossa história é deveras excepcional. A pandemia suscita a reflexão, acima de tudo, sobre a nossa condição humana. Discursos dos mais variados são proferidos e transmitidos todos os dias e dão conta de diversos aspectos da nossa condição e dos efeitos imediatos e duradouros da pandemia sobre nós. No que segue, quero apresentar ao leitor uma meditação filosófica sobre um dos tantos aspectos que a pandemia faz pensar: a vida e o viver através de uma reflexão racional e desapaixonada. Que quer dizer isso? Como farei essa abordagem?

No que segue, quero apresentar alguns tópicos clássicos do pensamento estoico providência, destino, liberdade - em consonância com a atmosfera própria desta escola filosófica. A princípio pode parecer deslocado o meu propósito, mas entendo que a filosofia não necessita de uma abordagem direta para ser compreendida. Hoje, mais do que nunca, carecemos de uma via oblíqua para abordar a vida humana através de um de seus aspectos mais decisivos: a finitude.

Reflexões acerca dos impactos econômicos, científicos, sociológicos e políticos da pandemia são os mais comuns. Um aspecto mais subterrâneo, o aspecto religioso-cristão, 
também é ratificado na linguagem do vulgo. São bem comuns tentativas de se "justificar" a situação atual como culpa dos "nossos" excessos, sinais evidentes do desvio do "caminho reto". Expressões como "só Deus pode nos salvar" não são confissões de fé, mas de desprezo pela ciência, ou seja, a negação taxativa de uma compreensão racional da nossa situação atual.

Não. Não pretendo entrar nesta seara. A filosofia pode obliquamente corroborar como tema sem tratá-lo diretamente. É isso que pretendo com o presente artigo: retomar um clássico tema da filosofia estoica. A escolha por esta "via" é uma forma de se afastar ao máximo do que se tornou tão trivial nas reflexões contemporâneas. A escolha do estoicismo é a um só tempo a suspensão da abordagem do tema sob o domínio da religião - uma vez o que o estoicismo é considerado (do ponto de vista da religião) uma filosofia pagã; suspensão também do domínio do "político" em sentido amplo, uma vez o que o estoicismo é uma filosofia marginal aos grandes sistemas, políticos, filosóficos, morais etc.

Duas grandes instâncias - uma externa e outra interna - serão mobilizadas no intuito de refletir sobre a nossa condição humana de seres racionais e finitos. Sob a perspectiva do indivíduo que reflete sobre os condicionamentos externos e internos que estão presentes no ato das escolhas individuais, o foco central do presente texto é a possibilidade de escolha, o que implica numa crítica sem apelo às superestruturas, mesmo aquela fornecida pela razão universal. Se esta é a consequência, a natureza deve surgir como instância máxima, como critério último para avaliar a vida através do viver e o viver através das escolhas.

\section{OS ESTOICOS E A DUPLA ABORDAGEM SOBRE O DESTINO}

Se algo merece ser chamado de "Problema da Providência", aos estoicos trata-se da tendência a substituir uma via interior exitosa a uma via cósmica que fracassa. Se suprimisse essa preocupação em se justificar aquilo que acontece, se provasse que o mal aparente é na realidade um bem, o sábio estoico não teria outra preocupação senão permanecer sereno diante de quaisquer que fossem os acontecimentos. Uma filosofia da ligação universal seria substituída por uma filosofia totalmente diferente, para não falar oposta - uma filosofia da separação e do isolamento do sábio.

A discussão deste item será consagrada à análise da via cósmica e seu fracasso inevitável. Ao analisar na segunda parte as razões que justificam o êxito da via interior, veremos que este sucesso é, em um sentido mais perigoso, ainda que o fracasso da via cósmica. O curvarse sobre a interioridade, o retrair-se, o recolhimento - é sem dúvida a tentação do estoicismo, 
mas isso já não é mais o estoicismo, visto que em tudo isso a ideia de providência desaparece. A doutrina tem então necessidade, pode-se assim dizer, de um contrapeso. O objetivo da terceira e última parte da análise abaixo será o de apresentar este contrapeso, partindo de uma das grandes metáforas do estoicismo, a metáfora do ator.

Neste item, o meu objetivo é caracterizar a ideia de providência nos estoicos. Me limitarei, portanto, ao estudo de uma concepção pagã da providência no contexto de uma filosofia que não admite a noção de criação ou de Deus criador. Qual a relevância da noção de providência nos estoicos? Como é sabido, não somente os estoicos discutiram os problemas inerentes à providência. Contudo afirmam, entre outras coisas, que foram os únicos a abordar verdadeiramente a providência. O ponto central da discussão encontramos em um trecho da obra de Epicteto intitulada Diatribes:

Sobre os Deuses, alguns dizem não existir o divino; outros dizem existir, porém ocioso, descuidado e imprevidente; em terceiro lugar, há os que dizem existir e ser previdente, mas quanto às coisas grandes e celestiais e não quanto às terrenas; em quarto lugar, há os que dizem serem previdentes também em relação às coisas terrenas e às humanas, mas só em relação às gerais e não às próprias de cada um; em quinto lugar, há aqueles, entre os quais se contam também Odisseu e Sócrates, que dizem "Movendo-me, não te escapo" (EPICTETO, 2020, I, 12, 1-3, p. 102').

Epicteto propõe aqui uma espécie de classificação progressiva dos filósofos antigos: 1) de início, identifica o ateísmo de alguns discípulos de Epicuro; 2) em seguida, a posição do próprio Epicuro (os deuses existem, mas não se ocupam de nós); 3) a seguir, aquela posição de Aristóteles na qual a ordem divina reina apenas no mundo celeste; 4) depois, apresenta a posição de alguns estoicos isolados (a providência só diz respeito ao conjunto, não ao detalhe) e, por fim, 5) a posição atribuída a Sócrates e ilustrada por uma frase de Ulisses na Ilíada que expressa a tese autêntica do estoicismo: a providência se estende até o mais ínfimo detalhe. A referência a Ulisses remete à prece à Palas Atena, como podemos ler na Ilíada:

Ouve-me, filha de Zeus poderoso, que em todas as minhas dificuldades me assistes, a quem não se ocultam meus passos, Palas Atena! Ora mais do que nunca propícia me ajuda. Da que possamos, cobertos de glória, voltar para as naves, pós grande feito acabarmos que há de lembrar sempre os Teucros. (HOMERO, 2015, X, vv. 277-82).

Na sequência de sua reflexão, Epicteto resume apenas a duas. Segundo ele, as quatro primeiras, apesar das diferenças aparentes, afirmam a mesma coisa: são apenas formas de dizer que os 
deuses não existem. O pressuposto de Epicteto é claro: se os deuses não estendem a sua providência a tudo, é um claro sinal de que eles não existem. Na obra Meditações de Marco Aurélio, encontraremos uma caracterização da ideia de providência enunciada por Epicteto, ou seja, uma ideia de providência que se estende ao todo e nos mínimos detalhes. Para compreender este princípio do tudo ou nada e suas consequências, consideremos duas ideias que se encontram em dois parágrafos sucessivos no livro VI das Meditações de Marco Aurélio:

$\$ 38$ Reflete frequentemente sobre o enlace das coisas todas no cosmos e sobre a relação de umas com as outras. De certa maneira todas estão trançadas uma com as outras, e todas por isso são amigas umas das outras; e, pois, uma coisa está em seqüência à outra, graças ao movimento coordenado e ao sopro conjunto e à unidade da substância. $\$ 39$ Com as ações que te tem designado a sorte, com essas harmoniza-te; e aos homens que compartilham da mesma sorte, a esses ama, mas verdadeiramente (MARCO AURÉLIO, 2019, VI, 38, 39, p. 181).

As primeiras palavras do parágrafo $§ 38$ reforçam a definição da providência estoica: a ligação de todas as coisas no mundo. A providência é esta simpatia universal em virtude da qual tudo existe em vista do todo, tudo é bom ao todo: os deuses velam essa relação. O bem de um deve ser o bem do outro. Se pudéssemos ver tudo, compreender tudo, fazer o cálculo exato de tudo, compreenderíamos que este entrelaçamento é uma amizade das partes entre si com o todo.

Retornando a Epicteto, podemos compreendê-lo melhor: ele afirma que aqueles que não veem os menores detalhes não compreendem nada da providência, nem dos deuses - pois toda obra divina repousa sobre a unidade do detalhe. Compreender a simpatia universal permite compreender a fragilidade do mundo, se assim se pode afirmar. Uma vez que todas as coisas estão intimamente ligadas umas às outras, seria suficiente alguém introduzir em um único ponto o acaso, ou seja, a ausência de causa para que o todo se rompesse. O todo é sensível à defecção da menor de suas partes. Por um lado, a sabedoria estoica consiste em harmonizar o mundo; por outro, essa harmonia é sempre acompanhada da ideia de que o próprio mundo tem necessidade deste acordo.

Nas primeiras linhas do $§ 39$ encontramos a definição estoica do "destino": o lote indicado a cada um, a parte que lhe é devida, inelutavelmente e com toda justiça, leva em conta a ligação de todas as coisas do mundo. $\mathrm{O}$ destino é aquilo que se aparenta à providência quando consideramos o indivíduo. Por isso a impressão de termos ficado com a pior parte: meu destino não é bom, eu sou pobre, doente, eu morrerei jovem etc. Mas, se em tudo compreendermos o 
entrelaçamento das coisas no mundo, veremos que o bem de um está ligado e constitui o bem do outro.

Esta identidade da providência divina e do destino indica que só existe para os estoicos o "fatalismo" no sentido exato do termo. O fatalista é aquele que crê que um acontecimento é escrito antes e que, por conseguinte, este acontecimento se realizará - por um caminho ou outro, quer queiramos ou não, independente do que fizermos para evitar - ele chegará independente do resto do mundo. $\mathrm{O}$ estoico afirma, ao contrário, que um acontecimento está ligado a todos os outros e que esta ligação - e apenas ela - lhe faz afirmar que o acontecimento em questão chegará necessariamente. Essa postura não é um fatalismo, mas sim um determinismo, uma filosofia da ligação universal: todas as coisas estão entrelaçadas com as outras.

Em seu Tratado Sobre o destino, Marco Túlio Cícero apresenta a diferença entre a posição do estoico Crísipo e aquela do fatalismo. Para isso, ele lança mão da noção de “confatalidade": as coisas são confatais ${ }^{\mathrm{ii}}$, quer dizer, fatais no conjunto - não são fatais sozinhas e independente uma das outras. Um exemplo ilustrativo é este: na afirmação "Édipo nascerá de Laio" não se pode acrescentar "quer Laio tenha estado ou não com mulher", pois esta última causa é um confatal, ou seja, um "fato associado" em relação ao primeiro fato, qual seja o necessário nascimento de Édipo. O exemplo a seguir também é esclarecedor:

Se o destino para ti é convalescer desta doença, quer tu tenhas consultado um médico quer não tenhas consultado, convalescerá; paralelamente, se o destino para ti é não convalescer desta doença, quer tenhas consultado um médico quer não tenhas consultado, não convalescerá - e outro destino existe para ti: logo, consultar um médico é indiferente (CÍCERO, 2001, XII, 29, p. 23).

Retornando às duas passagens citadas antes, Marco Aurélio não se contenta em definir a providência divina como uma ligação e o destino como lote. Ele nos diz algo mais: "Com as ações que te tem designado a sorte, com essas harmoniza-te". Se lermos esta afirmação de modo imperativo, fica claro que o interesse do estoicismo, na afirmação da providência divina, é a sabedoria que daí deriva e pode ser enunciada de modo imperativo: "harmoniza-te com o teu destino como lote que lhe coube"!

No século III a.C., o imperativo formulado por Zenão de Cítio, o fundador da escola estoica, era expresso assim: “... viver de acordo com a natureza, o que significa viver segundo a virtude.” (LAËRCE, VII, p. 847). Bem mais tarde, no século I d.C., o estoico Epicteto formulou o seguinte imperativo: "Não te procures que os acontecimentos aconteçam como desejas, mas deseja os acontecimentos como acontecem, e será feliz" (EPICTETO, 2016, VIII, 
p. 27). Quer seja formulado à maneira de Zenão ou àquela de Epicteto, o imperativo estóico se mostra sempre muito claro: ele ordena ao sábio dar seu assentimento àquilo que lhe acontece. No entanto, desde que consideremos a significação deste assentimento, desde que refletimos sobre aquilo que implica na realização deste imperativo, podemos hesitar entre duas vias, podemos ser arrastados em duas direções.

Em primeiro lugar, imperativos como "Viva segundo a natureza" ou "Não te procures que os acontecimentos aconteçam como desejas, mas deseja os acontecimentos como acontecem" podem ser entendidos como apelo ao conhecimento. O que conta em meu assentimento é que este é um assentimento à providência. O meu "não" significaria que eu desconheço sua bondade e o meu "sim" deve ser um reconhecimento desta bondade. Para querer as coisas que me acontecem como elas acontecem, tenho necessidade de saber como elas acontecem e compreender a ligação de todas as coisas no mundo. Eu acuso frequentemente os deuses: devo me dar os meios para corrigir este erro, adquirir os conhecimentos que me permitirão compreender que tudo é bom, que os deuses são inocentes. Esta primeira interpretação do imperativo estoico conduz assim àquilo que podemos chamar de "teodiceia", uma espécie de justiça divina.

Em segundo lugar, esse mesmo imperativo pode ser entendido de um outro modo. $\mathrm{O}$ que conta em meu assentimento é que este é a condição de minha felicidade, de minha capacidade de acolher cada acontecimento como expressão de meu consentimento. Meu "não" me colocaria em desacordo com aquilo que me acontece, meu "sim" é um ganho de adequação harmoniosa. Para meu assentimento não tenho necessidade absoluta de conhecer o detalhe do entrelaçamento das coisas, não preciso compreender de que modo exato me atenho ao todo, nem preciso saber com precisão porque os acontecimentos são assim. O que exige de mim, então, o imperativo "viva segundo a natureza" ou "não te procures que os acontecimentos aconteçam como desejas, mas deseja os acontecimentos como acontecem"? Certamente exige um trabalho interior, um trabalho sobre mim mesmo. Um certo grau de autoconhecimento me deixará disposto ao assentimento, prestes a conformar com tudo aquilo que me acontece, independente do que me acontece.

Podemos chamar esta primeira compreensão de "via cósmica", visto que exige que o ser humano se eleve a uma compreensão/visão de conjunto do mundo. Podemos chamar esta segunda compreensão de "via interior", visto que requer do ser humano um trabalho sobre si mesmo. De saída, algo fica evidente: a via cósmica tende ao fracasso, pois no fim das contas é 
impossível ao ser humano se elevar e julgar a partir do ponto de vista de Deus e a partir daí compreender o entrelaçamento de todas as coisas. A via interior tende a ser exitosa para aquele que leva a vida a sério, uma vez que não depende dele se proteger do sofrimento, de se evitar a injustiça ou se escapar da morte. O que depende sempre dele? Ele pode se proteger contra a crença que seus sofrimentos devem afetar, evitar se sentir humilhado pelas injustiças, saber escapar do pensamento segundo o qual a morte é um mal.

\section{O FRACASSO DA VIA CÓSMICA OU ACEITAÇÃO PURA DO DESTINO}

A via cósmica do estoicismo é aquela da teodiceia. Trata-se de fundar nosso assentimento em consonância com os acontecimentos, em particular daqueles acontecimentos que, a exemplo do sofrimento, da injustiça, da morte etc., são, sob nosso ponto de vista, acontecimentos infelizes, escandalosos, que nos incitam a acusar os deuses. Trata-se de nos elevar ao ponto de vista divino, de demonstrar o caráter providencial destes acontecimentos, compreendendo suas ligações com todos os outros acontecimentos. O paradigma aqui encontrase naqueles acontecimentos bem realizados e, do ponto de vista do todo, coerentes. Em outros termos, a via cósmica requer nosso assentimento dos acontecimentos que nos sucedem sob o olhar da eternidade.

Qualquer coisa parece poder nos colocar sobre a via de uma tal compreensão: o fato de que tudo é sinal de tudo. Cada acontecimento atual é o sinal de todos os acontecimentos passados, o sinal anunciador de todos os acontecimentos futuros e o sinal contemporâneo de tudo aquilo que se passa ao nosso redor. O conhecimento requerido deve, portanto, ser uma interpretação. Preciso exercitar a minha capacidade de conhecer ao máximo as diversas conexões entre os fatos, para sofrer menos.

A justificação dos acontecimentos pode ir realmente até os menores detalhes? É notável que a teodiceia pareça ridícula quando assume esta pretensão, como se alguém tomasse consciência da desproporção entre nosso poder de interpretar e o entrelaçamento infinito das coisas. É possível, por exemplo, levar Epicteto a sério quando, querendo cantar um hino à providência, ele justifica a barba no queixo de uma parcela dos seres humanos apenas porque a barba serve para distinguir de longe o homem da mulher (Cf. EPICTETO, 2020, I, 16, 9-12, p. 117)?

Geralmente, a teodiceia não tem a pretensão de demonstrar que tudo aquilo que nos acontece é bom: ela se contenta em demonstrar que aquilo que nos acontece é bom para o todo ${ }^{\mathrm{iii}}$. 
Vejamos como Epictero desenvolve o preceito zenoniano “viver segundo a natureza". É da natureza do pé que ele seja meu, comenta Epicteto. Mas, se considerarmos o pé tal como ele é, quer dizer, como uma parte do corpo, compreendemos que ele deve por vezes ser sujo, pois precisa tocar a lama ou ensanguentado, visto que pode ser furado por um espinho e/ou amputado. Assim também tu, que lamentas dos deuses, é sem dúvida, conforme a tua natureza, que sejas rico e em boa saúde se se considera isoladamente; mas, se se considera como aquilo que tu és, quer dizer, como uma parte da cidade universal, convém por vezes que tu fiques doente, sem socorro ou que morras prematuramente no interesse do todo (cf. EPICTETO, 1997, II, 5).

Invocar deste modo o interesse do todo é dar um primeiro passo na via cósmica em direção à via interior. Visto que o assentimento do sábio estoico não repousa mais sobre um conhecimento efetivo da ordem do mundo, mas sobre um saber presumido, ou seja, sobre aquilo que ele compreenderia se fosse capaz de esclarecer o labirinto dos acontecimentos. O que substitui o conhecimento ausente é um trabalho sobre si mesmo contra as paixões egoístas que nos incitam sempre às considerações isoladas. Não existe nada de mal na exigência de uma teodiceia perfeita? Querer justificar a barba no queixo, querer esclarecer a providência justa nos menores detalhes é correr o risco de alimentar as reivindicações individualistas, de justificar as paixões que reconduzem tudo a si. Este caminho é impedido quando pensamos o sentido do todo, quando afirmamos o interesse do todo.

Não se trata, no entanto, de uma impossibilidade teórica de compreender o entrelaçamento das coisas. É uma exigência prática inerente à sabedoria estoica que explica este primeiro recuo da teodiceia em relação ao seu projeto inicial. Um segundo recuo consiste em deslocar/substituir a finalidade pela necessidade, o raciocínio em termos de meios e de fins para um raciocínio em termos de causas, de efeitos e de leis.

Consideremos um outro texto de Epicteto sobre a providência (EPICTETO, 1997, III, 17). Ao discípulo lamentando que o homem injusto tenha melhor sorte que ele (velha acusação contra a providência), Epicteto não responde invocando o interesse do todo, mas a necessidade bruta. Que o homem injusto tenha mais dinheiro que tu estás na ordem das coisas: o que lhe importa é saber que ele adula, visto que ele é imprudente etc. - em suma, que ele é injusto e recebe o exato salário de sua injustiça. Tu não deves admirar que cada um tenha mais que o outro no domínio onde ele é superior e, sobretudo, tu não deves te irritar visto que tu tens a 
melhor parte. Existe aí uma nova maneira de enunciar a providência: afirmar que o mundo é bom, não no sentido finalista, mas em um sentido determinista ou necessitarista.

Que fazer, pergunta Marco Aurélio, quando nos deparamos com a vigarice de um homem? O filósofo não responde a esta questão tentando explicar por que um mundo contendo este homem é melhor que um mundo que não o contém. Ele responde colocando uma outra questão: “É possível então não haver sem-vergonha no mundo?” (MARCO AURÉLIO, 2019, IX, 42, p. 283). O determinismo é substituído pelo finalismo. Deparamos novamente com aquilo que não é apenas uma dificuldade teórica que incita o estoico a renunciar sua pretensão inicial: é sobretudo o perigo de fornecer uma interpretação que faria elogio às paixões egoístas, por exemplo, as paixões de um discípulo que quisesse ter o melhor dos dois mundos: as vantagens da sabedoria e aquelas vantagens que a sabedoria exige que ele abandone.

Do mesmo modo se considerarmos não mais a interpretação dos fatos presentes, mas aquela dos fatos futuros, quer dizer, se levarmos em conta a adivinhação - prática tão importante no mundo antigo. De início, não existe nenhuma razão no estoicismo para se opor à adivinhação; há até mesmo uma forte razão para aceitá-la como saber definido pela providência. $\mathrm{O}$ entrelaçamento universal de todas as coisas poderia justificar a prática da adivinhação. $\mathrm{O}$ pressuposto exigido ao pensamento seria este: a benevolência dos deuses não pode impedir o nosso acesso ao conhecimento futuro.

De todo modo, os estoicos criticam frequentemente a adivinhação pela mesma razão que foi exposta antes, visto que ela corre o risco de exaltar as paixões egoístas. É preciso, portanto, encontrar o meio de combinar a aceitação do princípio e da crítica ética. É isso que propõe o seguinte texto de Epicteto: “Como é preciso praticar a adivinhação" (EPICTETO, 1997, II, 7). É geralmente por más razões, afirma Epicteto, que nós procuramos o adivinho. De fato, no geral, procuramos o adivinho porque tememos ou esperamos a realização de certas profecias. Temor e esperança são formas inadequadas de manifestação das paixões: as paixões tristes, na linguagem de Spinoza.

Qual seria o modo correto de recorrer aos deuses? Epicteto aconselha: é preciso procurálos como um viajante que se endereça a qualquer um na rua para saber que rota tomar, sem ter o desejo de ir particularmente pela direita ou pela esquerda, mas querendo conhecer a rota que conduz ao seu destino. Epicteto reconhece, portanto, que o bom adivinho tem o poder de nos dizer qual é a melhor rota, mas ele afirma acima de tudo que nós devemos abordá-lo tendo 
extirpado de nós os desejos e os temores. O importante não é a adivinhação em si mesma, mas o fato de saber como praticá-la.

Do que foi dito até aqui sobre a via cósmica, podemos constatar o seguinte: o seu fracasso reside no fato de que somos finitos e mesmo conhecendo o todo, somos incapazes de agir à semelhança dos deuses - temos nossas paixões, não somos imortais. A crítica de Epicteto não é à adivinhação, mas à razão pela qual recorremos a ela. O motivo pelo qual recorremos à adivinhação revela o fracasso da via cósmica e o peso das paixões. É necessário, dada a impossibilidade prática da via cósmica, passar da primeira para a segunda via, ou seja, da via cósmica à via interior.

\section{A VIA INTERIOR OU O PROBLEMA DA COEXISTÊNCIA ENTRE LIBERDADE E PROVIDÊNCIA}

A ideia da providência de que tudo é regido por uma divindade benevolente se depara tradicionalmente com duas objeções: a) se é assim, o mal não deveria existir - no entanto, existe; b) a providência é incompatível com a liberdade. A via cósmica do estoicismo pretende resolver o primeiro problema do mal formulado na tese acima: se conhecêssemos o entrelaçamento universal, veríamos que o mal é reabsorvido no bem. Quanto mais nos distanciarmos da via cósmica, mais nos distanciaremos deste problema. O resultado do distanciamento da vida cósmica nos aproxima de um outro problema: como minha liberdade pode coexistir com a providência?

A vida interior é inaugurada por aquela distinção que abre o Manual de Epicteto: "Das coisas existentes, umas estão em nosso poder e outras não estão em nosso poder.” (EPICTETO, 2016, I, 1, p. 19). Uma tradução que muda a palavra, mas ganha em sentido, poderia ser esta: "Há coisas que dependem de nós e coisas que não dependem de nós." Em um universo de coisas entrelaçadas, as coisas se ligam umas às outras e são causas umas das outras. De um lado, esta frase separa, colocando de um lado todas as causas que abatem sobre mim e, de outro lado, me isola enquanto causa. No primeiro caso, estão as coisas que o destino me reservou (aquilo que não depende de mim); no segundo, minha liberdade (aquilo que depende de mim).

A frase de Epicteto estabelece, portanto, um corte no interior da providência: em um sentido, ela destrói esta noção e a cinde em dois pedaços disjuntos. Para reencontrar a ideia de providência, precisa juntar (colar) estes pedaços, ou seja, compreender como o destino e a liberdade podem colaborar. O risco é bem visível: o perigo é se ater à cisão, se 
comprazer/aquiescer a ela. A primeira inspiração do estoicismo seria traída caso eu optasse por um dos polos, ou seja, pelo destino ou pela liberdade, separadamente.

Como se faz a articulação entre destino e liberdade? O texto fundamental sobre esta questão é uma passagem famosa do Tratado Sobre o destino (XIX, 43, p. 31). Na referida passagem, Cícero faz Crísipo falar, desenvolvendo uma de suas imagens favoritas, a imagem do cilindro e do cone: de um lado uma coisa que rola em linha reta quando repousa; de outro, uma coisa que, ao receber a mesma impulsão inicial - sofrendo, portanto, o mesmo destino -, se comporta diferente, visto que sua forma própria o incita a girar sobre ele mesmo.

O destino afirma a sua essência: uma cascata infinita de causas exteriores resultando no movimento do dedo que impulsiona o cilindro ou o cone. Para Crísipo, estas são todas causas “próximas", “adjuvantes", "secundárias". Para Epicteto, fazem parte das coisas que não estão em nosso poder. Ao contrário, é "essencial" ou "perfeita" a causa interna, a tendência própria ao cilindro rolar e ao cone girar. Esta propriedade está contida no lote das coisas que estão em nosso poder, ou seja, na nossa liberdade. Mas, o que permite aplicar ao homem esta imagem do cilindro e/ou do cone? Leiamos Cícero citando Crísipo:

Portanto - diz ele - como aquele que empurrou o cilindro lhe deu princípio de movimento, porém não lhe deu rotação, assim aquela representação apresentada imprimirá sua imagem em nossa alma, mas nosso assentimento estará em nosso poder, e, do mesmo modo que se disse do cilindro, impulsionado de fora, ele se moverá quanto ao resto por sua própria força e natureza (CÍCERO, 2001, XIX, 43, p. 31).

O homem, a exemplo do cilindro, deve ser definido por sua tendência natural: a tendência natural do cilindro é rolar em linha reta, a tendência natural do homem é dar seu assentimento àquilo que lhe parece verdade, dar seu assentimento àquilo que se lhe apresenta como verdade ou existente; e recusar seu assentimento àquilo que se lhe apresenta como falso ou inexistente. Esta é a noção exata da liberdade absoluta de todo ser humano: assentir àquilo que depende exclusivamente dele, assentir àquilo que "está em seu poder". Ninguém pode constranger um homem de dizer sim àquilo que lhe parece falso. Se alguém deseja isso de alguém, trata de arranjar de tal modo que ele possa crer ser verdade. Em suma, é preciso se dar o trabalho de enganar, mentir.

Se o encadeamento das causas exteriores determina um homem a cair doente em um determinado momento, este encadeamento diz respeito à própria doença, à "doença bruta": ela não engloba a opinião que o homem em questão teria de sua doença - opinião que não depende 
do próprio homem. Porém, é esta opinião, e não a doença propriamente dita, que o domina. Todas as ideias que testemunham neste homem a recusa da doença - a ideia de que a doença é má, escandalosa, injusta e desesperante -, serão de algum modo acrescentadas por ele àquilo que ele deve sofrer.

A verdadeira causa da infelicidade humana está contida nestes acréscimos que o próprio homem faz sobre aquilo que lhe acontece. É uma espécie de "causa parasitária" que o homem acrescenta ao que lhe acontece o que torna insuportável o seu destino. É preciso abolir este acréscimo, esta parasitagem. Essa abolição não pode ser feita através do conhecimento do todo, e sim através da crítica de sua própria representação das coisas. É este trabalho sobre si que a via interior convida cada um, como propõe Marco Aurélio.

Dize a ti mesmo nada mais do que as precedentes impressões anunciam. Foi anunciado que um tal fala mal de ti. Foi anunciado isso; isto, porém, que foste prejudicado, não foi anunciado. Vejo que o menininho está doente. Vejo; mas que esteja em perigo não vejo. Assim então mantém-te sempre sobre as primeiras impressões, e nada acrescenta tu mesmo interiormente, e nada te acontece; e, antes, acrescenta como um que descobre cada uma das coisas que ocorrem no cosmos (MARCO AURÉLIO, 2019, VIII, 49, p. 251).

Certamente, na última frase da citação acima, Marco Aurélio mantém a referência à via cósmica da interpretação dos acontecimentos. Mas, as frases que precedem mostram como a crítica das representações ${ }^{\text {iv }}$ permite ao sábio se harmonizar com o mundo e realizar o imperativo estoico. Se ele diz "sim” ao seu destino, é para neutralizá-lo, reduzindo-o aquilo que ele é: ele o acompanha para não precisar sofrer.

O imperativo é cristalino: "nada acrescenta tu mesmo interiormente, e nada te acontece". Nós estamos aqui sobre um terreno escorregadio, visto que é tentador dar outro sentido à crítica das representações: não mais criticar as representações para aguardar a harmonia com as coisas, mas criticar as representações para não ser invadido, para permanecer tranquilo em si mesmo, aí onde "nada acontece". Se fosse este o caso, não seria mais um problema colaborar com o destino, mas estar bem abrigado.

A própria ideia da providência, ou seja, a ligação universal, desapareceria em proveito de um pensamento do isolamento. Se assim fosse, sairíamos do estoicismo. Este é o risco da via interior, risco do qual testemunham diversos pensamentos de Marco Aurélio sobre o "recolhimento". Seria vulgar de tua parte, diz ele para si mesmo, querer fazer como os ricos 
romanos que fogem dos tormentos da cidade, recolhendo-se em suas casas de campo, sobre a praia ou nas montanhas:

Procuram refúgios para si, casas de campo e costas litorâneas e montanhas; e costumas também tu desejar sobretudo tais isolamentos. Tudo isso, porém é o que há de mais vulgar, já que podes, à hora que quiseres, recolher-te em ti mesmo. Pois em nenhuma parte um homem se recolhe nem mais tranqüila nem mais calmamente do que na própria alma, sobretudo aquele que tem dentro de si tais qualidades sobre as quais basta inclinar-se para adquirir imediatamente total conforto, e por conforto não digo outra coisa que boa ordem. Continuamente então proporciona a ti mesmo esse refúgio, e renovate; porém haja nele conceitos concisos e elementares que, imediatamente tendo sido encontrados, bastarão para conter todo tormento e reenviar-te livre de irritação àquelas ocupações para as quais retomas (MARCO AURÉLIO, 2019, IV, 3, p. 93).

Em vez de buscar fora, eis a via interior, retorne a hora que quiseres para dentro de $\mathrm{ti}^{\mathrm{v}}$, pois aí o homem está abrigado e é o mestre de seu momento. É no interior que é possível se consagrar, instante após instante, ao "tema" que lhe propõe o acontecimento afim de se harmonizar, sem rigidez ou de modo dogmático, a tudo aquilo que o destino lhe apresenta. $\mathrm{O}$ texto é, todavia, ambíguo, pois após afirmar que ele só se recolhe tranquilo em sua alma, o imperador-filósofo acrescenta que tal afirmação pressupõe que tenha em si condições de gozar de conforto, ou seja, boa ordem. Nós encontramos aqui a ordem do cosmo, a ordem providencial a qual a crítica das representações permite aderir com certo "conforto", ou seja, com certa facilidade.

A tendência ao recolhimento e a indiferença ao mundo não estão menos presentes nesta segunda via do estoicismo. Como é próprio da filosofia estoica, a doutrina só se mantém suscitando um contrapeso: sem retornar à primeira via, ou seja, à pretensão de compreender o entrelaçamento universal. O homem precisa encontrar uma nova razão para afirmar a providência, quer dizer, o caráter bom dos acontecimentos. Este contrapeso será apresentado a partir de uma imagem ou metáfora que é aquela do ator - muito difundida nos textos do estoicismo e da tradição estoica ${ }^{\mathrm{vi}}$.

\section{A METÁFORA DO ATOR}

Esta metáfora é famosíssima em toda a literatura sobre o estoicismo. Antes de mais nada, é necessário lê-la na íntegra, como segue: 
Lembra-te de que és ator dum drama tal como quiser o autor [da peça]: curto, se curto; longo, se longo. Se ele quiser que representes o papel de mendigo, [assim o quererá] para que também o representes convenientemente; [e igualmente] se o de coxo; se o de magistrado; se o de indivíduo particular. Pois isto, representar belamente a personagem dada, é teu; escolhê-la, porém, é de outrem (EPICTETO, 2016, XVII, p. 35).

A maior parte das pessoas não admite que desempenha um papel: a seus olhos, isso seria reduzir a vida a uma espécie de farsa (comédia). Porém, é exatamente o contrário para o filósofo estoico. Os "comediantes" no sentido pejorativo, são justamente aqueles que se tomam por personagens, que se identificam com sua personagem. O sério da vida é, a exemplo do bom ator, o homem que encena, mas que não "se" encena. Ao se identificar com o seu personagem, o mau ator vive preocupado com aquilo que vai acontecer (aquilo que lhe sobrevém na vida), em vez de se consagrar em sua única tarefa, que é colaborar com o seu destino. Colaborar com o seu destino é desempenhar bem seu papel, é dizer o que é preciso ser dito quando é preciso ser dito, tendo o cuidado, instante após instante, com a perfeição de seu gesto e da justa entonação da voz.

Reconhecemos o mau ator por suas perpétuas recriminações: ele queria atuar em outra peça ou ter um outro papel; queria não morrer no terceiro ato - quando a peça é composta de cinco atos. Em suma, ele gostaria, como diz Epicteto, que o seu papel fosse trocado e o seu "tema" fosse outro. Entretanto, o poder de mudar ou adaptar o "tema" faz parte daquilo que não depende de nós. O que depende de nós é tratar corretamente de desempenhar o papel, qualquer que seja ele.

Assim como foi apresentada, esta metáfora do ator se inscreve, portanto, na segunda via do estoicismo. Ao aconselhar o bom preparo para realizar bem o meu papel sem me preocupar com o resto, a metáfora apela àquela instância "do que não depende de nós". Atuar bem e não questionar por que foi nesta peça e não em outra que eu fui escalado para atuar ou por que é este personagem e não outro que eu devo interpretar. A metáfora não pretende justificar que o fato de desempenhar bem o papel demonstra que a peça é boa: a via cósmica é inteiramente rejeitada. De todo modo, se nós desenvolvermos as consequências desta metáfora do ator, veremos que a noção de providência retorna em função do valor operatório que ela tinha ao passar da via cósmica para a via interior.

A primeira destas consequências é que um bom ator desempenha todos os papéis, o que significa dizer que ele não é apegado a nenhum papel em particular. Qualquer que seja seu papel, uma espécie de reserva marcará o poder que ele tem de desempenhar uma infinidade de 
outros e manifestará a sua superioridade de ator para reportar à sua personagem e, assim, ele reporta a todos os personagens. É isso que constitui o valor do homem, a sua dignidade.

Da capacidade do bom ator em desempenhar todos os papeis resulta, paradoxalmente, a seguinte constatação: há papéis melhores que outros. Seu critério, no ato de hierarquização dos papéis não deve levar em conta os papéis mais fáceis de encenar, e sim os papéis mais difíceis, aqueles que estão à altura do sentimento que tem de seu valor, de sua dignidade, de sua superioridade sobre todos os papéis. Quando Epicteto quer ilustrar esta virtude "esportiva" da dificuldade, ou seja, a ideia que é o obstáculo que permite o valor se manifestar, ele cita o exemplo de Hércules.

Imaginemos Hércules sem as provas que lhes foram impostas, Hércules sem o leão de Neméia, sem a Hidra de Lerna, sem a corça de Cerineia, sem o javali de Erimanto... sem os homens injustos e brutais que o perseguiram e dos quais ele tinha que purgar a terra. Imaginemos Hércules com todas as suas faculdades, com seus braços, seu vigor, sua compostura, sua generosidade, sem as circunstâncias que solicitaram seu exercício, sua expressão. É claro que Hércules não seria Hércules se tivesse passado por sua vida reservado e gozando de luxo e repouso. Seria necessário, pergunta Epicteto, que Hércules inventasse para si mesmo suas provas para suplantá-las, que ele mesmo introduzisse os monstros nos países? Rejeitemos esta ideia louca e convenhamos que é através deste esforço no mundo que Hércules se encontrou quando realizava as provas que ele suplantou para ser quem realmente é.

Eis aí como a providência é reencontrada, mas desta vez, a partir da segunda via, da distinção entre aquilo que depende e aquilo que não depende de nós. Os pedaços se colam, as coisas que não dependem de Hércules (o leão, a hidra etc.) e aquelas que dependem dele (como suas faculdades) se harmonizam em um mundo bem-organizado. Reencontramos a noção de providência e a ideia de que o nosso assentimento não é bom somente para nós ou para nossa felicidade, mas para o próprio mundo. Relembremos: uma vez que a providência é uma ligação de todas as coisas, uma simpatia universal que chega até os menores detalhes, é sensível à eventual defecção deste menor detalhe.

Pois fica mutilado o todo se acaso tenhas cortado algo da conexão e consistência tanto das causas como das partes. E quebras o quanto depende de ti, quando estejas descontente, e de certo modo o destróis (MARCO AURÉLIO, 2019, V, 8, p. 135). 
O destino tem, portanto, necessidade de que eu diga "sim". Certamente, mesmo se eu lhe disser "não" ele me arrastará ${ }^{\text {vii }}$. Fica patente na história de Hércules que num mundo em que vivem monstros existe a necessidade de Hércules do mesmo modo em que Hércules tem necessidade de um mundo em que vivem monstros. Essa nova maneira de mostrar sem passar por uma teodiceia em que o mal aparente é um bem real, Sêneca resume em uma palavra em seu Tratado Sobre a providência divina: ocasião. Eis o texto na íntegra:

Eu vos imploro, não tenhais tamanho pavor disso que os deuses imortais lançam aos espíritos como estímulos: a calamidade é a ocasião da virtude. A outros se poderia chamar com razão infelizes, aos que se tornam malemolentes sob esta excessiva felicidade, aos que, como um mar em calmaria, a tranqüilidade modorrenta paralisa: o que quer que os atinja, os pegará de surpresa (SÊNECA, 2000, 4.6, p. 45, grifos meus).

O homem que era tentado a se retirar do mundo para escapar dos sofrimentos, das crueldades e das injustiças aparentes pode, então, se abrir com confiança. Os dois problemas que se colocam à noção de providência conseguem triunfar mesmo onde o fracasso da via cósmica era patente. A metáfora do ator parece, todavia, uma espécie de limite e podemos nos perguntar se isso não limita também a reabilitação da ideia de providência. Como procuramos mostrar, a aptidão para desempenhar indiferentemente todos os papéis define o valor do homem, o que tem por consequência paradoxal que alguns papéis - aqueles que solicitam este valor - são melhores que outros. Mas resulta também na possibilidade de se recusar certos papéis, aqueles que são incompatíveis com este valor, contrários a esta dignidade: este é o sentido do suicídio estoico.

É claro que poderíamos ver nesta recusa de seu papel uma maneira de dizer "não" ao destino, uma daquelas pequenas defecções que destroem, virtualmente, a ordem do mundo. Em suma, um ato contrário à doutrina e que só seria aceito a título de caso-limite, como uma prova que o ideal estoico é, no final das contas, inacessível. No entanto, a possibilidade do suicídio é apresentada por Epicteto como pertencente plenamente à metáfora do ator: ao mesmo tempo que ele recomenda ao seu discípulo se lembrar de que ele é um ator, ao passo em que também solicita ao discípulo ter sempre presente: "Eis o principal: lembra-te que a porta está aberta" (EPICTETO, 2020, I, 25, p. 148). Se é claro que eu tenho o direito de recusar certos papeis, é para poder preservar em meu papel de homem, este papel superior a todos os papeis que me foram confiados - visto que este papel (ser humano) é que me habilita a desempenhar todos os demais. 


\section{CONCLUSÃO}

A tendência natural do homem consiste em dar seu assentimento àquilo que lhe parece verdadeiro, bom, justo, razoável e recusar aquilo que lhe parece falso, mau, injusto, não razoável. Isso vale para todos os homens, sábios ou não. O homem sábio é aquele que não se opõe ao princípio que o conduz a fazer aquilo que é razoável ou não razoável. Este juízo, porém, depende da maneira com a qual um e outro - aquele que se opõe e aquele que não se opõe ao princípio razoável da harmonia do cosmos - apreciam o valor dos objetos exteriores, mas também seu próprio valor.

Certos homens têm uma ideia muito rasteira de sua dignidade e estão prestes a aceitar tudo para sobreviver. Portanto, a tudo julgar razoável: é notável que estes sejam precisamente aqueles que passam seu tempo se lamentando de sua vida, recriminando contra a sorte, lançando impropérios contra os deuses. Pertence ao sábio se harmonizar de bom grado ao destino e ter, ao mesmo tempo, uma elevada ideia de sua dignidade. Ao sábio estoico é razoável se manter na vida, mas lembrando-se que a porta está sempre aberta.

O preço da vida, cada um fixa o seu. Apesar da aparência, o suicídio estoico não é um abandono do posto, uma defecção. É um suicídio por obediência: obediência àquilo que prescreve a razão, obediência à sua própria humanidade. Ele não suprime a colaboração do sábio com o seu destino. Viver conforme a natureza é, por vezes, morrer conforme a natureza. Nenhum ator é obrigado a desempenhar um papel que coloque em risco a condição como ator. Assim como o autor, nenhum ser humano está obrigado a realizar atividade que o deponha como a sua natureza (humana) e o desagregue física, ética ou moralmente.

\section{REFERÊNCIAS}

AGOSTINHO. A verdadeira religião. São Paulo: Paulus, 2002.

CÍCERO, Marco Túlio. Sobre o destino. São Paulo: Nova Alexandria, 2001. [Bilíngue].

DESCARTES, René. CEuvres de Descartes. Publiées par Charles Adam \& Paul Tannery. Paris: Vrin, 1982 [11 volumes].

DINUCCI, Aldo. O conceito estoico de phantasia: de Zenão a Crisipo. Archai: revista de estudos sobre as origens do pensamento ocidental, n. 21, set.-dez., 2017, p. 15-38. 
DIOGÈNE LAËRCE. Vies et doctrines des philosophes ilustres. Paris: La Pochothèque, 1999.

ÉPICTETE. Entretiens: livres I à IV. Paris: Gallimard, 1997.

EPICTETO. Manual de Epicteto - ou recomendações estoicas para o bem viver. Belo Horizonte: Nova Acrópole, 2016 [Bilíngue].

As diatribes de Epicteto: livro 1. 2019. Disponível em: https://digitalisdsp.uc.pt/bitstream/10316.2/47835/1/Diatribes.pdf, acessado em 15/05/2021.

FOUCAULT, Michel. O filósofo mascarado. In: . Arqueologia das ciências e história dos sistemas de pensamento. 2 ed. Rio de Janeiro: Forense Universitária, 2005, p. 299-306 (Coleção: Ditos e escritos II).

GAZOLLA, Rachel. Cosmologia do estoicismo antigo: existência, "sub-existência" e destino. In:__ (ORG.). Cosmologias: cinco ensaios sobre filosofia da natureza. São Paulo: Paulus, 2008, p. 83-131.

HOMERO. Ilíada. 25 ed. Rio de Janeiro: Nova Fronteira, 2015.

LAURAND, Valéry. Le vocabulaire des stoïciens. Paris: Ellipses, 2002.

SAMB, Djibril. Étude du lexique des stoïciens. Paris: L’ Harmattan, 2009.

SÊNECA, Lúcio Aneu. Cartas a Lucílio. 4 ed. Lisboa: Calouste Gulbenkian, 2009.

Sobre a providência divina • Sobre a firmeza do homem sábio. São Paulo: Nova Alexandria, 2000 [Bilíngue].

TAYLOR, Charles. As fontes do self: a construção da identidade moderna. São Paulo: Loyola, 1997.

VOLTAIRE, François-Marie Arouet. Cândido ou o otimismo. São Paulo: Editora 34, 2013.

\section{NOTAS}

\footnotetext{
${ }^{\text {i }}$ Recentemente saiu publicada a tradução do Livro I das Diatribes realizada pelo professor Aldo Dinucci, da Universidade Federal de Sergipe. Esta tradução foi publicada em e-book e está disponível na íntegra na internet: https://digitalis-dsp.uc.pt/bitstream/10316.2/47835/1/Diatribes.pdf. Farei referência ao longo do presente texto a esta obra quando a citação se referir ao livro I, caso contrário, farei a partir da edição francesa, uma edição completa das Diatribes.

ii Reproduzo aqui a nota da tradução da obra Sobre o destino: “'Confatal' é, aqui, palavra forjada para uma exata tradução do texto: Copulata enim res est et confatalis. O sentido de res confatalis é 'coisa sujeita ao mesmo destino" (CÍCERO, 2001, p. 56, nota 56). A estudiosa do estoicismo, Rachel Gazolla, no capítulo Cosmologia do estoicismo antigo: existência, "sub-existência” e destino (2008, p. 128 ss), sem fazer nenhuma referência a Cícero, utiliza o termo confatalidade para traduzir a expressão grega argòs lógos. No contexto do tema estudado aqui, ou seja, no contexto da providência-destino-liberdade, não parece acertado a tradução da expressão grega por confatalidade: "Adentrar no argos lógos é buscar a leitura de como a Phýsis se entrelaça, e sempre será de modo
} 
necessário. Podemos afirmar que algo se deu por acaso porque, rigorosamente, não sabemos ler as causas antecedentes de modo amplo.” (idem, p. 129). Não estou certo se essa interpretação se aplica à providência, pois não se trata de um "trabalho do logos" (argòs lógos), no sentido de que ele precisa ser corretamente aplicado e sim de um imperativo (obrigação que conduz à obediência, inquestionável), como deixa entrever a concepção que consta em Cícero.

iii Esta é uma das principais caraterísticas dos Ensaios de teodiceia, escritos por G. W. Leibniz (2013) e acidamente criticados por Voltaire em seu Cândido (2013).

iv O termo representação, na tradição estoica, é sinônimo de "impressão na alma" e diz respeito ao modo como temos acesso ao mundo sensível. Representação não possui um caráter negativo e/ou se equivale a imaginação ou fantasia. A representação é um momento no processo de aquisição do saber e, por isso mesmo, deve passa por um processo de depuração (Cf. verbetes Representação e Representação cataléptica, em LAURAND (2002) e SAMB (2009) e sobre o a tradução do termo phantasia para o português (Cf. DINUCCI, 2017)).

${ }^{\vee} \mathrm{O}$ pressuposto absolutamente necessário para o alcance da felicidade é o conhecimento. A felicidade é o objeto do nosso desejo e o conhecimento é o meio para sua aquisição. Não é possível pensar na felicidade sem que o espírito (nous) possa conduzir a alma a um objeto permanente e imutável. Em chave estoico-cristã, esta busca interior coincide com a busca de Deus. É por isso que Agostinho, o bispo de Hipona, aconselha em sua obra $A$ verdadeira religião: Noli foras ire, in teipsum redi; in interiore homine habitat veritas "Não saias de ti, mas volta para dentro de ti mesmo, a verdade habita no coração do homem." (AGOSTINHO, 2002, p. 198). Charles Taylor, filósofo contemporâneo, em seu livro As fontes do Self (1997), no famoso capítulo "In interiore homine" dedicado a Agostinho, defende a tese segundo a qual o eu interior de Agostinho deva ser compreendido em sua relação consigo mesmo em relação como Deus (o superior). Nada proíbe pensar que este homem interior de Agostinho é fruto de sua meditação sobre o que ele conhecia do estoicismo antigo via Cícero, sobretudo se levarmos em conta os elogios rasgados ao Hortênsio de Cícero - obra hoje perdida que ele faz menção em suas Confissões.

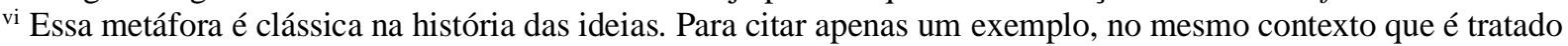
aqui, cito o exemplo de Descartes (filósofo moderno). Reforçando a tese de que seguir a lógica da razão na maioria das vezes é negar a lógica da multidão, ele anotou em um texto da juventude (Cogitationes privatae) esta ideia: "Do mesmo modo que os comediantes estão atentos para cobrir com o rouge (avermelhado) o que lhe aparece no rosto, ao representar o seu papel, do mesmo modo, no momento de subir à cena deste mundo, onde eu estou aqui apenas como espectador, eu caminho mascarado [larvatus prodeo].” (A.T. XI, p. 213-14). Essa divisa (metáfora) hoje em dia serve - para os detratores da reflexão filosófica séria - para questionar as reais intenções de Descartes. Recentemente, no ano de 1980, o filósofo francês Michel Foucault concedeu uma grande entrevista ao jornal $L e$ monde (n. 10.945, 6 de abril de 1980: Le monde-dimanche, pp. I e XVII). Ele aceitou conceder esta entrevista com a condição de que o seu nome e toda referência que pudesse identificá-lo fosse suprimida. À época ele justificou que o contexto assim exigia, pois as "estrelas" (e ele era uma delas) estavam se sobrepondo às ideias, não permitindo o debate. O título desta entrevista, síntese do experimento, é justamente uma homenagem a Descartes e se intitula: O filósofo mascarado. O texto está traduzido e acessível nos Ditos e escritos, II, p. 299-306.

vii Para os estoicos, o destino é algo que eu não posso me furtar. Em uma de suas Cartas a Lucílio (Carta 107, 11), Sêneca, tomando como base trechos de um antigo texto de Cleantes, faz uma verdadeira oração nos seguintes termos: "Guia-me, ó pai que reges o excelso céu, para onde te aprouver: não hesitarei em obedecer-te; aqui estou, sempre pronto! Se resistir, terei de seguir-te gemendo, suportando de má vontade o que podia ter feito de bom grado. O destino guia quem o segue, arrasta quem lhe resiste!” (SÊNECA, 2009, p. 590). 